\title{
PEMETAAN BATIMETRI PANTAI MALALAYANG DUA, KOTA MANADO
}

\author{
(BATHYMETRY MAPPING OF MALALAYANG DUA COAST, MANADO CITY)
}

\section{Abdulrahman Lahay', Rignolda Djamaluddin', Hermanto W.K Manengkey', Brama Djabar $^{2}$}
1) Program Studi IImu Kelautan, Fakultas Perikanan dan IImu Kelautan, Universitas Sam Ratulangi Manado
2) Perkumpulan KELOLA, Manado Scientific Exploration Team
*email: aminlahay958@gmail.com

\begin{abstract}
As with other coastal areas, Malalayang Dua Coast has been used for various activities and is predicted to continue to grow along with the development of Manado City. To support efforts to manage and utilize coastal space in an effective and sustainable manner, data and information are needed related to oceanographic factors, one of which is the bathymetry condition of the coastal waters. This research was carried out with the aim of describing the bathymetric conditions and analyzing the slope of the bottom of the waters. The depth measurement by acoustic method was carried out along 15 survey lines and 750 fixed measurement points, and the bathymetry map was drawn with reference to Mean Seawater Level (MSL). The results obtained indicate that the bathymetry of Malalayang Dua Coast in the west has shallow waters that are wider than the eastern one. Meanwhile, parts of the waters deeper up to a depth of $50 \mathrm{~m}$ appear to be steeper in the West than on the East side. In the middle part of the observed waters, there is a part that is relatively deep and protrudes towards the land with a steeper side towards the east. The slope of the bottom of the water in the west (Profile 1) is indicated by flat slopes (2.6\%) to a depth of $7 \mathrm{~m}$, and slopes (13\%) at a depth of $7 \mathrm{~m}$ to $50 \mathrm{~m}$. In the middle section (Profile 2) the slope is categorized as gentle (3\%) to a depth of $4 \mathrm{~m}$, and inclined slopes $(10 \%)$ at a depth of $4 \mathrm{~m}$ to $50 \mathrm{~m}$. In the eastern part (Profile 3 ) the slopes are categorized as sloping slopes (10.28) to a depth of $35 \mathrm{~m}$, and gentle slopes (3.42\%) at a depth of $35 \mathrm{~m}$ to $50 \mathrm{~m}$.
\end{abstract}

Keywords: bathymetry, acoustics, slope, Malalayang Dua Coast

Sebagaimana wilayah pantai pada umumnya, Pantai Malalayang Dua telah dimanfaatkan untuk berbagai aktivitas dan diprediksi akan terus berkembang seiring perkembangan Kota Manado. Untuk menunjang upaya pengelolaan dan pemanfaatan ruang pantai secara efektif dan berkelanjutan, diperlukan data dan informasi terkait faktor oseanografi dimana salah satu yang penting yaitu kondisi batimetri perairan pantai tersebut. Penelitian ini dilaksanakan dengan tujuan untuk menggambarkan kondisi batimetri dan menganalisis kemiringan lereng dasar perairan. Pengukuran kedalaman dengan metode akustik dilakukan sepanjang 15 lajur perum dan 750 titik fix perum, dan peta batimetri digambarkan dengan referensi Muka Laut Rata-rata (Mean Seawater Level - MSL). Hasil yang diperoleh menunjukkan bahwa batimetri Pantai Malalayang Dua sebelah Barat memiliki perairan dangkal yang lebih lebar dibandingkan sebelah Timur. Sementara itu, untuk bagian perairan yang lebih dalam hingga kedalaman $50 \mathrm{~m}$ nampak lebih terjal di bagian Barat dibandingkan sisi sebelah Timur. Pada bagian tengah perairan yang diamati, terdapat bagian yang relatif dalam dan menjorok ke arah darat dengan sisi yang lebih terjal ke arah sebelah Timur. Kemiringan lereng dasar perairan di sebelah Barat (Profil 1) terindikasi lereng datar (2,6\%) hingga kedalaman $7 \mathrm{~m}$, dan lereng miring $(13 \%)$ pada kedalaman $7 \mathrm{~m}$ hingga $50 \mathrm{~m}$. Pada bagian tengah (Profil 2) kemiringan lereng terkategori landai (3\%) hingga kedalaman $4 \mathrm{~m}$, dan lereng miring (10\%) pada kedalaman $4 \mathrm{~m}$ hingga $50 \mathrm{~m}$. Pada bagian Timur (Profil 3) kemiringan lereng terkategori lereng miring $(10,28)$ hingga kedalaman $35 \mathrm{~m}$, dan lereng landai $(3,42 \%)$ pada kedalaman $35 \mathrm{~m}$ hingga $50 \mathrm{~m}$.

Kata kunci: batimetri, akustik, kemiringan lereng, Pantai Malalayang Dua 


\section{PENDAHULUAN}

Wilayah pantai merupakan daerah yang sangat intensif dimanfaatkan untuk kegiatan manusia. Beragam bentuk peruntukan lahan di wilayah pantai antara lain: pusat pemerintahan, pemukiman, industri, pelabuhan, pertambakan, pertanian/ perikanan, dan pariwisata (Triatmodjo, 2012). Diprediksi bahwa aktivitas pembangunan di wilayah pantai akan semakin masif ke depan seiring perkembangan populasi dan ekonomi suatu wilayah. Berbeda dengan aktivitas di daratan, pembangunan fisik dan pemanfaatan ruang di wilayah pantai harus ditopang oleh data dan informasi oseanografi, salah satunya terkait visualisasi kontur dan kedalaman perairan.

Survei batimetri perlu dilakukan untuk mendapatkan data kedalaman dan visualisasi kontur atau topografi dasar perairan. Menurut Poerbandono dan Djunarsjah (2005), survei batimetri meliputi proses penggambaran dasar perairan yang dimulai dari pengukuran, pengolahan, hingga visualisasi dasar perairan. Salah satu teknik pengukuran kedalaman yaitu dengan perangkat akustik berdasarkan prinsip rambatan suara dalam media air. Teknik ini dipandang cukup efektif (Prananda et al., 2017). Kedalaman perairan didapat dari setengah perkalian antara cepat rambat gelombang akustik dikali selang waktu pada saat dipancarkan dan diterima kembali oleh transducer (Edi, 2009). Menurut Hermawan (2007), hidroakustik merupakan teknologi pendeteksian bawah air menggunakan perangkat akustik seperti echosounder, fish finder, dan sonar. Hasil kajian awal, wilayah pesisir Malalayang Dua lebih cocok untuk pengembangan pariwisata (Syafi'l et al., 2001). Sekarang, Pantai Malalayang Dua yang menjadi lokasi studi tergolong pantai dengan pemanfaatan yang relatif masif. Berbagai jenis aktivitas di tempat ini, yakni: wisata pantai, pelatihan dan wisata selam, transplantasi karang, lokasi tambatan fasilitas transportasi laut tertentu dan perahu nelayan, alur navigasi sarana transportasi tertentu, dan juga menjadi wilayah tangkap nelayan untuk ikan-ikan demersal dan pelagis kecil. Pengaturan pemanfaatan ruang secara tepat dengan tanpa merugikan keberlangsungan sumber daya alam serta timbulnya konflik atau salah pemanfaatan ruang menjadi hal yang sangat penting dilakukan. Beberapa contoh permasalahan yang telah terjadi antara lain: perusakan ekosistem terumbu karang yang diakibatkan oleh kesalahan bernavigasi yang menyebabkan kandasnya kapal angkut material (tongkang), kekeliruan dalam pemilihan lokasi untuk transplantasi terumbu karang, dan konflik antara nelayan dengan pemangku kepentingan di beberapa lokasi tertentu. Studi batimetri menjadi penting untuk mendukung pengambilan keputusan yang tepat terkait pemanfaatan ruang perairan pantai yang menjadi lokasi studi.

Survei batimetri dengan perangkat akustik digunakan untuk pengukuran kedalaman perairan pantai di lokasi studi. Studi ini juga secara khusus dilakukan untuk menghitung koreksi pasang-surut dengan referensi Mean Seawater Level (MSL), dan juga penggambaran profil dan klasifikasi kemiringan lereng dasar perairan. Diharapkan hasil studi ini berupa peta batimetri, profil penampang dan kemiringan lereng dasar perairan dapat bermanfaat bagi pemanfaatan ruang pantai di lokasi studi secara optimal dan berkelanjutan.

\section{METODE PENELITIAN}

\section{Waktu dan Lokasi penelitian}

Pengukuran kedalaman perairan
yang dilakukan bersamaan dengan

\section{Alat dan Bahan}

Beberapa peralatan yang digunakan dalam penelitian ini, yakni: Fish finder FF700 untuk pengukuran kedalaman, GPS Garmin 76CSx untuk penentuan posisi geografis, palem pasang surut permanen 


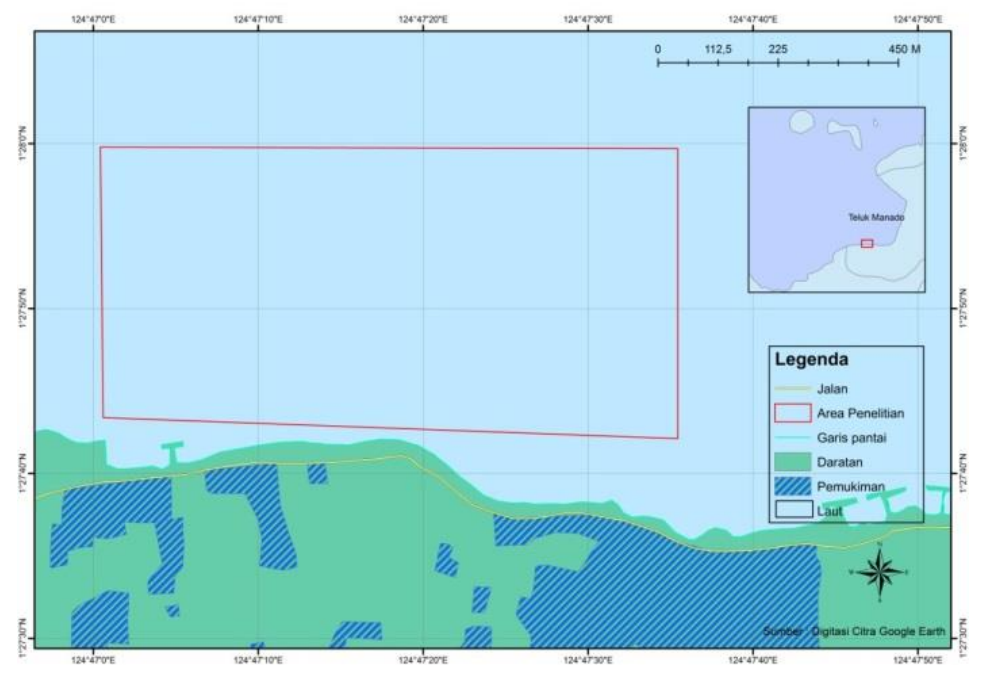

Gambar 1. Peta Lokasi Penelitian

untuk pengukuran tinggi permukaan laut. Bahan penelitian berupa Citra Satelit bersumber dari Google Earth (10-06-2018) digunakan sebagai peta setelah terlebih dahulu dilakukan koreksi geometrik menggunakan ArcGIS 10.3. Perangkat ArcGis 10.3 juga digunakan untuk penggambaran peta batimetri. Perangkat Surfer 13 digunakan untuk menampilkan garis kontur dan profil penampang dasar perairan.

\section{Pengumpulan Data}

Pengukuran kedalaman mengikuti 15 lajur perum dan 750 titik fix perum seperti pada Gambar 1. Pada setiap perubahan kedalaman yang terdeteksi pada Fish Finder, dilakukan pengukuran kedalaman dan pengambilan posisi geografis. Data pasang surut diamati setiap periode 15 menit selama waktu pengukuran kedalaman dan interval pengamatan setiap 1 jam selama 39 jam. Data pasang surut yang diamati setiap 15 menit digunakan untuk mengoreksi kedalaman terukur, sementara itu data setiap interval 1 jam digunakan untuk menghitung MSL. Perhitungan MSL menggunakan Metode Filter Doodson (Ongkosongo, 1989; Mutiara, 2018).

\section{Analisis Data}

Data batimetri yang telah terkoreksi kemudian dihitung dengan formula berikut:

$$
\mathrm{D}=\mathrm{H}_{\mathrm{ukur}}+\mathrm{dT} \pm \mathrm{rt}
$$

Dimana: D (kedalaman sebenarnya), $\mathrm{H}_{\text {ukur }}$ (kedalaman terukur), dT (kedalaman tranduser), rt (koreksi pasang surut - nilai pengamatan tinggi muka laut saat pengukuran kedalaman relatif terhadap MSL).

Data kedalaman yang telah dikoreksi kemudian diinterpolasi dan diextrapolasi menggunakan metode kringing pada Surfer 13 untuk menghasilkan kontur kedalaman. Selanjutnya, ArcGIS 10.3 digunakan untuk pembuatan peta batimetri.

Analisis morfologi dasar laut berupa kemiringan lereng diperoleh dari perhitungan menggunakan peta kontur batimetri yang dihasilkan. Nilai kemiringan diperoleh menggunakan metode Wentworth (Arifianti, 2011). Adapun persamaannya disajikan sebagai berikut:

$$
S=\frac{(n-1) \times I c}{\Delta h} \times 100
$$

Dimana: $S$ (nilai kemiringan lereng dalam persen), $\mathrm{n}$ (jumlah kontur), Ic (interval kontur), $\Delta \mathrm{h}$ (jarak horizontal dalam meter)

\section{HASIL DAN PEMBAHASAN}

\section{Batimetri Perairan Pantai Malalayang Dua}

Pada Gambar 2 ditampilkan hasil pengolahan data kedalaman perairan pantai Malalayang Dua dengan referensi MSL $113 \mathrm{~cm}$. Dengan jarak garis kontur yang cukup rapat (setiap interval $2 \mathrm{~m}$ ) nampak jelas peta batimetri perairan tersebut dengan cukup detil. Secara 


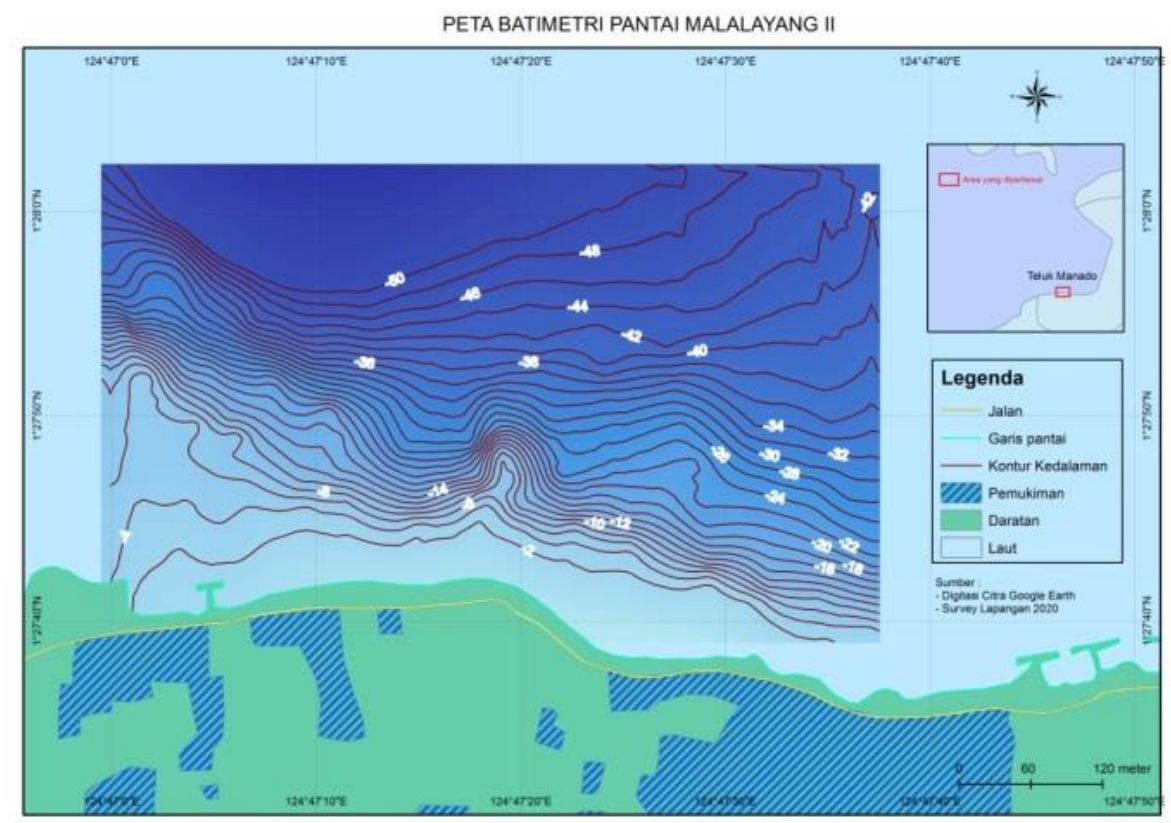

Gambar 2. Peta batimetri Pantai Malalayang Dua

umum, lebaran perairan yang relatif dangkal nampak lebih lebar di bagian Barat dibandingkan sisi sebelah Timur. Sebaliknya, sisi sebelah laut hingga kedalaman $50 \mathrm{~m}$ nampak lebih terjal di bagian Barat dibandingkan sisi sebelah Timur. Nampak pula pada peta tersebut perbedaan lebaran wilayah perairan dengan kedalaman $10 \mathrm{~m}$, dan jarak antar kontur yang bervariasi setelah kedalaman $10 \mathrm{~m}$. Jarak kontur yang sangat berdekatan menunjukan laju penambahan kedalaman yang cepat atau topografi yang terjal (Pipkin et al., 1987) seperti pada beberapa titik di sisi sebelah Barat dan juga di bagian tengah sekitar lokasi terdapatnya bagian perairan yang relatif dangkal dan menjorok ke arah laut.

Lebih jauh, beberapa hal berikut perlu mendapat catatan. Pertama, pada sisi sebelah Barat kondisi topografi dasar perairan nampak lebih bervariasi dengan pola bergelombang dengan lebaran yang relatif sempit. Pola ini nampak lebih teratur di sisi sebelah Timur hingga kedalaman sekitar $40 \mathrm{~m}$. Pada sisi sebelah Timur pola topografi berbentuk gelombang nampak lebih lebar, dan antara kedalaman $40 \mathrm{~m}$ dan $50 \mathrm{~m}$ pola topografi berupa gelombang tidak nampak. Kedua, adanya bagian perairan yang relatif dalam di sisi bagian tengah yang menjorok ke arah darat dengan sisi yang lebih terjal ke arah sebelah Timur. Masyarakat mengenal lokasi ini dengan istilah "lobang atau bermakna lubang", dan penyelam free diving menggunakan lokasi ini untuk aktivitas mereka. Ketiga, topografi perairan antara $10 \mathrm{~m}$ dan $20 \mathrm{~m}$ di sisi sebelah Timur nampak berpola gelombang yang teratur dengan tinggi yang melandai ke arah Timur.

\section{Profil Penampang}

Profil penampang merupakan bentuk tampilan secara vertikal yang menggambarkan konfigurasi permukaan bumi sepanjang garis terpilih pada sebuah peta topografi atau peta batimetri (Setyono, 1996). Secara detil, profil penampang perairan pada tiga titik terpilih ditampilkan seperti pada Gambar 3 dan 4.

Berdasarkan hasil perhitungan menggunakan persamaan Wentworth dan kriteria kemiringan lereng yang dikemukakan oleh Sunarto (1991), diperoleh bahwa hingga kedalaman $7 \mathrm{~m}$ pada profil 1 terkategori lereng datar dengan tingkat kemiringan 2,6\%. Setelah kedalaman $7 \mathrm{~m}$, kemiringan lereng terkategori miring dengan tingkat kemiringan $13 \%$ Berdasarkan pengamatan di lapangan, area yang terkategori lereng datar berupa rataan terumbu karang. 


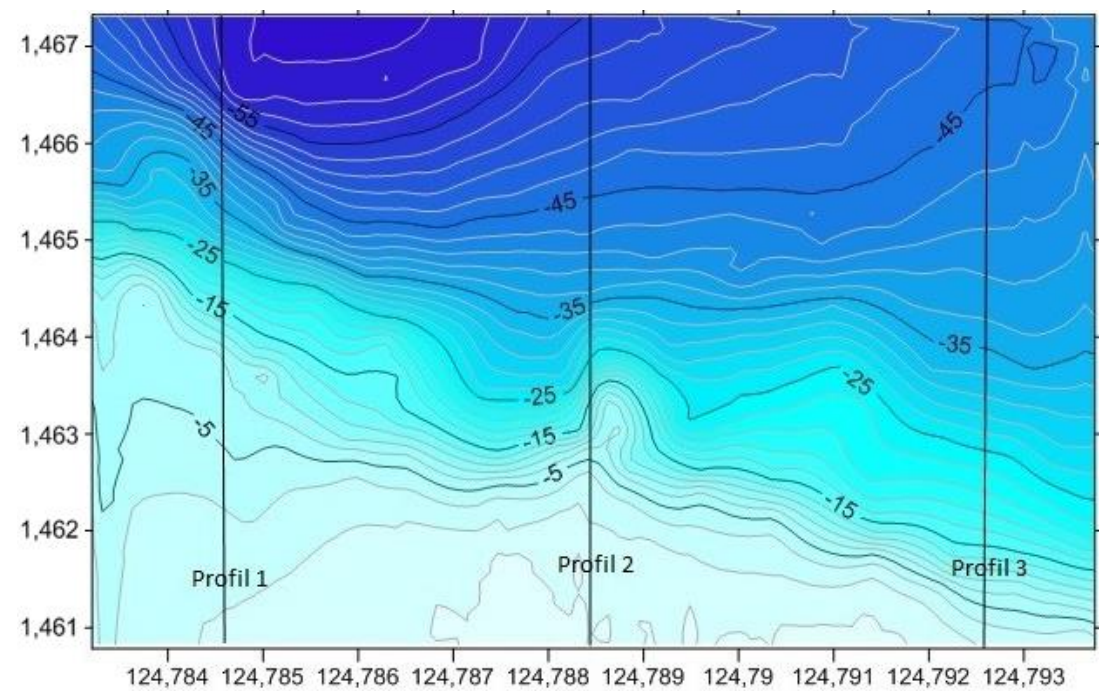

Gambar 3. Posisi Profil 1-3 pada Peta Kontur
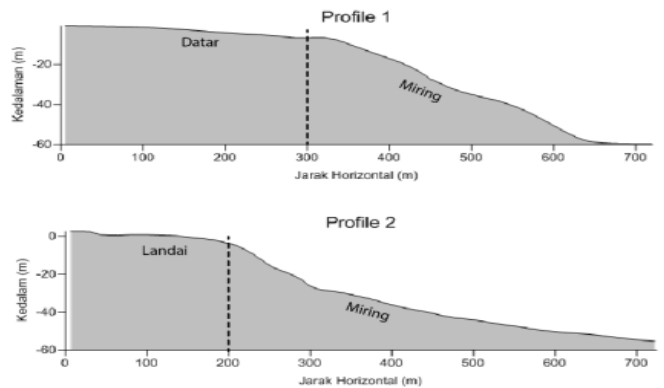

Profile 3

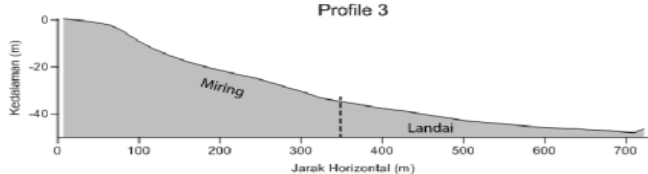

Gambar 4. Kemiringan lereng pada Profil $1-3$

Pada profil 2, hingga kedalaman $4 \mathrm{~m}$ terkategori lereng landai dengan tingkat kemiringan $3 \%$. Setelah kedalaman $4 \mathrm{~m}$, kemiringan lereng terkategori miring dengan tingkat kemiringan $13 \%$. Pada profil 3 hingga kedalaman $35 \mathrm{~m}$ terkategori lereng miring dengan tingkat kemiringan $10,28 \%$. Setelah kedalaman $35 \mathrm{~m}$, kemiringan lereng terkategori landai dengan tingkat kemiringan 3,42\%.

\section{KESIMPULAN}

Teknik batimetri yang diaplikasikan dapat menggambarkan secara detil peta batimetri dan karakteritik kemiringan lereng dasar perairan Pantai Malalayang Dua. Antara tiga bagian pantai yang dianalisis, nampak bahwa perairan yang relatif dangkal di sisi sebelah Barat lebih lebar dibandingkan sisi sebelah Timur. Sementara itu, sisi sebelah laut hingga kedalaman $50 \mathrm{~m}$ nampak lebih terjal di bagian Barat dibandingkan sisi sebelah Timur. Pada bagian tengah perairan yang diamati, terdapat bagian perairan relatif dalam yang menjorok ke arah darat dengan sisi yang lebih terjal ke arah sebelah Timur. Kemiringan lereng pada bagian Barat (Profil 1) terkategori lereng datar $(2,6 \%)$ hingga kedalaman $7 \mathrm{~m}$, dan lereng miring (13\%) untuk kedalaman selanjutnya hingga $50 \mathrm{~m}$. Pada bagian tengan (Profil 2) terkategori lereng landai $(3 \%)$ hingga ke dalaman $4 \mathrm{~m}$, dan lereng miring (10\%) untuk kedalaman selanjutnya hingga $50 \mathrm{~m}$. Pada bagian Timur (Profil 3) terkategori lereng miring (10,28\%) hingga kedalaman $35 \mathrm{~m}$, dan lereng landai $(3,42 \%)$ untuk kedalaman selanjutnya hingga $50 \mathrm{~m}$. 


\section{DAFTAR PUSTAKA}

Arifianti, Y., 2011. Potensi Longsor Dasar Laut di Perairan Maumere. Bulletin Vulkanologi dan Bencana Geologi, Volume 6 Nomor 1. Hal. 53-62.

Edi, B.P., 2009. Aplikasi Instrumen Akustik Multibeam dan Side Scan Sonar di Perairan Sekitar Teluk Mandar dan Selat Makassar. Institut Pertanian Bogor. Skripsi. $68 \mathrm{Hal}$.

Hermawan., 2007. Pembuatan Peta Batimetri Menggunakan Data Multibeam EM 1002 dan Perangkat Lunak CARISH HIPS-SIPS 5,4 di Selatan Bali. Skripsi. Universitas Gadjah Mada. Yogyakarta

Mutiara, I. 2018. Tinjauan Elevasi Puncak Bangunan Seawall di Pantai Galesong Utara. Intek Jurnal Penelitian. Volume 5 Nomor 2. Hal. 98-103.

Ongkosongo, O.S.R dan Suyarso. Lembaga IImu Pengetahuan Indonesia. Pusat Penelitian dan Pengembangan Oseanografi. Jakarta. Hal 201-230.

Poerbandono dan E, Djunarsjah., 2005.Survei Hidrografi. Refika Aditama. Bandung. 166 hal.

Prananda, A.R.A., Merici, A.C.W.B., Huda, A.N., Amalia, A., Nastiti, A.,
Wijayanto, G.N., Alfi, H.N., Yuda, L.D.P., Kartika, M.R.S.B., Wibowo, T.W. Pembuatan Peta Batimetri Dengan Menggunakan Metode Hidroakustik Studi Kasus Sebagian Sungai Cijulang Kabupaten Pangandaran, Jawa Barat. Proceedings of $5^{\text {th }}$ Geoinformation Science Symposium 2017. Hal. 138143.

Setiyono, H., 1996. Kamus Oseanografi. Gadjah Mada University Press. Yogyakarta. 210 hal.

Sunarto., 1991. Geomorfologi Pantai. Pusat Antar Universitas IImu Teknik. Universitas Gadjah Mada. Yogyakarta. 52 hal.

Syafi'i, B.I.E., Bengen, D.G., Gunawan, I., 2001. Análisis Pemanfaatan Ruang Kawasan Pesisir Teluk Manado, Sulawesi Utara. Jurnal Pesisir dan Lautan. Volume 4 Nomor 1. Hal. 116.

Triatmodjo, B., 2012. Perencanaan Bangunan Pantai. Beta Offset. Yogyakarta. 295 hal.

Pipkin, B.W., D.S Gorsline., R. E. Casey and D.E. Hammond., 1987. Laboratory Exercises in Oceanography. Second Edition. W.H. Freeman and Compan. New York. 257 hal. 